\title{
LA-UR $92-0224$
}

LA-UR- $-92-224$

DE92 007432

TITLE GET HIGH SCHOOL STUDENTS HOOKED ON SCIENCE WITH A CHALLFNGF

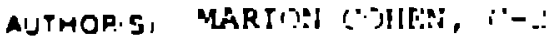

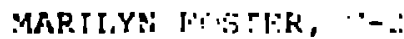

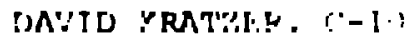 \\ INATRICIA MAIONIF, I'-. \\ ANH GOLEM, C-?
}

\section{A4 \\ P.}

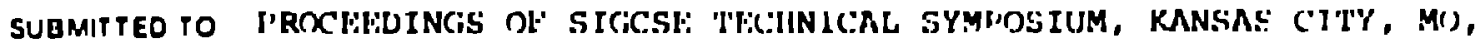
MARCH 5-6, 1992 .

\section{DISX:LAIMER}

This report eas prepared as an ecownt of whek spmenwed by an agency of the IIniled Silaten

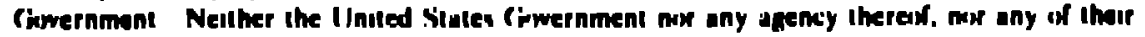

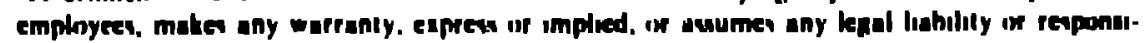
hiluy for the eccuracy. completenew, ur usefulnew of any informalmon, apparalus, product, of

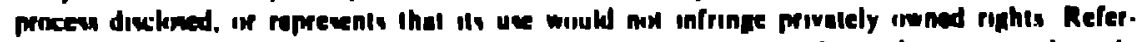

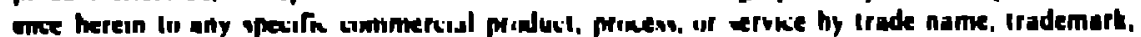

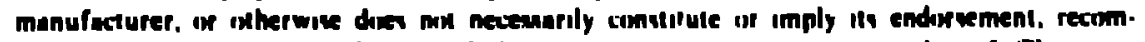

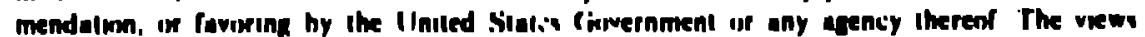

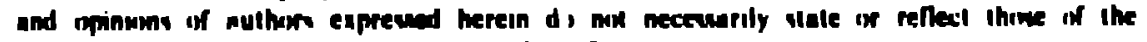
Inited Silntem (bovernment or any apancy ihereor

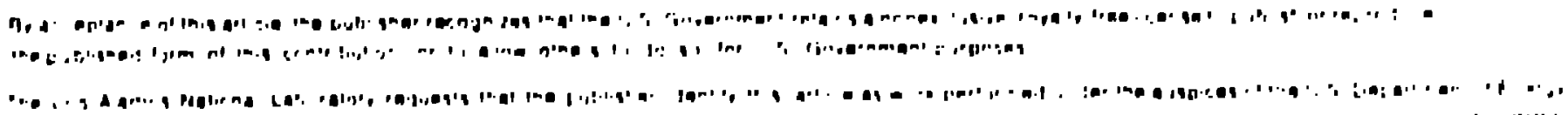


Get High School Students Hooked on Science with a Challenge

\begin{tabular}{|c|c|c|c|c|}
\hline $\begin{array}{l}\text { Marion Cohen } \\
\text { mfc@lanl.gov } \\
(505) \text { 667-4695 }\end{array}$ & $\begin{array}{l}\text { Marilyn Foster } \\
\text { msf@lanl.gov } \\
(505) 665-1014\end{array}$ & $\begin{array}{l}\text { David Kratzer } \\
\text { dhk@lanl.gov } \\
(505) 667-5745\end{array}$ & $\begin{array}{l}\text { Patricia Malone } \\
\text { pxm@lanl.gov } \\
(505) 667-3193\end{array}$ & $\begin{array}{l}\text { Ann Solem } \\
\text { avs@lanl.gov } \\
(505) 667-5460\end{array}$ \\
\hline \multicolumn{5}{|c|}{$\begin{array}{c}\text { Computing and Communications Division } \\
\text { Los Alamos National Laboratory } \\
\text { Los Alamos, NM } 87545\end{array}$} \\
\hline
\end{tabular}




\title{
Get High School Students Hooked on Ssience with a Challenge
}

\begin{abstract}
Stilled scientists and engineers along with a public that understauds science and technology are vital in today's lechnically comperitive world. The United States must encourage its students to study and excel in scientific academic subjects and consider science and engineering as a possible career.

An academic program that progresser from a state-wide to a national competition is a way of developing science and computing knowledge among high school students and teachers, as well as instiling enthusiasm for science. This paper describes the New Mexico High School Supercompuing Challenge, a nonselective academic-year long program that was initiated in 1990. Teams of high school students from throughout New Mexico do a team compularional science project using high-performance computers.
\end{abstract}

\section{Introduction}

Since the launching of Sputnik by the USSR in the 1950s, the Inited Stutes has realized the need for increased scientific knowledge at all educational levels to supply well trained scientists and enginecrs for rescarch and industry'. The nation also needs a scienufically licerate pub!ic that can function i'ı a technological workplace and will suppon lechnological progress.

\subsection{Need to Enhance Science Fiducation}

While science education has made some progress, there is much yet to be done to meet the nitional goals of well trained scientists and a technologically literate public. This need his been described in many repons, including the Lex Repon (1), Nation at Risk (2). Science for All Americ ans [3], and the Nationul Stience Froundation NSï) repurt

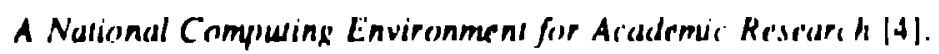

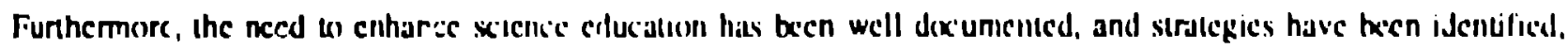
most recently in en NSF study on th tole of high-perfomance computing in science colucation $|5,6|$. 


\subsection{Abundance of Existing Expertise}

This country's universities and national laboratories have a wealth of scientific and technological experise and many resources that can be brought to bear w enhance science education. These technical resources, combined with the experise and interest of the education and business communities, can be brought together to create a cooperative educational environment that provides more effective science education

Our approach is to capilalize on existing technology and business resources, the hunger for knowledge among teachers and students, the traditional role of nonselective extra-curricular aclivities in high schools as a motivator for additional academic studies. the model of compelitive science fairs and sports, and the excitement that state-of-the-an computing can bring w students and teachers.

\section{Method}

In this paper, we describe the features of the New Mexico High School Supercomputing Challenge, explain how the program was conducted, outline the elements that have been most imporant for success, and delineate how this progtram is different from others $[7]$.

\subsection{Why Supercomputers for High School Students?}

Although high school stude ti, may not need to use supercomputers fer the size and complexity of the:r pivilems, supercomputers and high-performance computing methodolngy san be instrumentid in getting the attention of tcenagers. attracting them to science and technolog', and ulumately honking them on science, Just as teenigers are naturally interested in high-performanze cars, giving them the chance to use high-performance computers can make a difference.

High school is the time when students develop career interests and lasting altutudes towird science and enginecring. Successfully using superomputers at this stige sels a foundattion for future computang and ssicntific endeavors by 
- giving confidence and e،thusiasm to try academically challenging work,

- instilling excitement for science and computing, and

- providing the thrill of working on the best, most powerful equipment available.

The effects that supercompulers can have on students has been observed in a high school supercompuling program in Alabama [8]. Many students who previously voiced no interast in continuing their education beyond high school completed the supercomputing program with a strong desire to pursue a carcer in science, enginecring, or computer science.

\subsection{Goals}

The goals of the New Mexico High School Supercomputing Challenge are the following:

- Increase scicnce and computing knowiedge at the high school level.

- Promole carcers in science and enginecring.

- Encourage students to compele academically and give them the experience and confidence to enter national competitions.

- Reduce the isolation of tearhers in remile areas by putting them in electronic touch with their colleagues at other schools.

- Take advantape of existing science and computing expertise and resources for the henefil of high school teachers and students.

- Develop programs that can be replicated and may serve as models for other educational conımunities.

\subsection{Fealures of the New Mexico Program}

The New Mexico Supercomputing C'hallenge is an acidemic-year long program for high s'h(x)l students throughout New Mexico to do compulatinnal science projects using high-performiance commputers, It was contecived in 
the summer of 1990 by Senator Pelc Domenici of New Mexico and John Rollwagen, chairman and chief executive officer of Cray Rescarch, Inc., and was conducted during the 1990-91 academic year.

Fach team is composed of 1-5 students, their sponsoring teacher, and a science coach from academia or a rcscarch laboratory. The team defines and works on a single compulational project of their own choosing.

The Challenge is open 10 all students on a noriselective basis. In the first year of the program, 2.35 students on 65 teams with 55 teachers al 40 schools participated. More than 50 coaches and 10 judges voluntsered their scientific knowledge and their time to provide a rewarding experience for the teachers and students. Awards include scholarships and savings bonds for winning students and computing equipment for their schools.

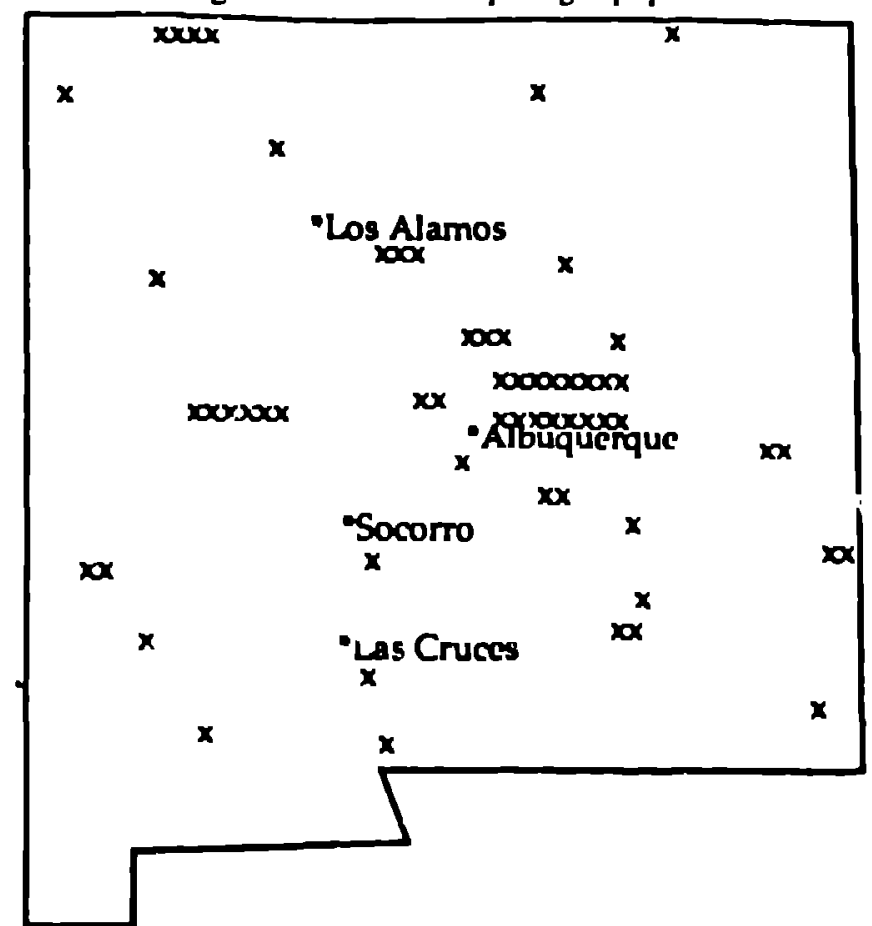

Figure I. On this map of New Mcxico, you can see that the teams are locaied all over the state, far from the sponsoring institutions in the mojor citiss.

\section{- Purticifation on a Nonselective Husk}

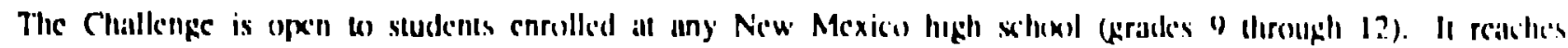
students a schex)ls where computing cquipment and computing courses may not be avidilahle, as well as swhexhls thall 
have equipment and advanced-level computing courses. Becaus: there is a vide variation of knowledge ameng the students, ihe emphasis is on achievement, or competition at each team's own level.

The program reaches many swdents who are historically underrepresented in scientific fields. In the initial program in 1990-91, women represented $25 \%$ of the students and $35 \%$ of the teachers, and three teams were all women. Many Hispanic students, students from severa! other ethnic groups, and students frum the New Mcxico School for the Visually Handicapped paricipated. We hope to increase participation by secking the suppon of organizations that promole awareness and academic involvement for these groups.

\section{- Access to Computer Archifectures and National Computer Networks}

Students are provided compuler time on CRAY Y-MP/264, Connection Machine CM-2, Convex C22U, IBM 3090300E, and VAX computers, where they explore the different architectures in linding solutions to their problems. More than 125 hours of computer time were used by participants during the academic year.

New Mexico Technet proviues stale-wide compuler nelwork access to thesi computers via $1-800$ and local telephene lines.

\section{- Ongoing Support}

Throughout the Challenge, a wide varicly of support is provided-training and computer documentation, equipment lons, communications and computing uroubleshooting and consulting, and scientific coaching. Students and teachers are brought together in Ocloher to receive two days of training to help them get stanc d.

Truining: At the Ucbober workshup, scientists talk aboul supercomputing and its application in different scienufic ficlds. Computer consulants give a hands-on-workshop where partucipants log on to the computcrs through dhe communicutions network and usc basic commands of compile and run a sumple program.

Fqulpment: Because many schexis do not hive adequali cquipment fo access the neiwork and supercomputcrs, terminals or workstutions und moderns are lent (o) hose s'h(x)ls.

In the 199()$-91$ (hallenge, 72 pieces of hardware and 4 weflwall packuges were provided to 33 sch(x)ls (R2\% of the panicifuting $w h(x) l s)$. 
Computer und Communications Consulting: Throughout the year, computer consulunts at Lus Alamos are available to answer questions and solve programming problems, and personnel at New Mexico Techulet handle communications questions and problems.

Technical Coach: Each team is assigned a technical coach îrom cither academia or a scientific research laboratory. The coach is familiar with supercomputing and the scientific area of the project and helps the team design its prnject, suggests additional or alternate approaches to the topic, answers questions, and offers encouragement.

Point of Contact: A point of contact at Los Alamos National Laboratory helps teachers identify problems and hurdles and secks solutions to eliminate these hurdles. The contact talks with teachers, takes requests for equipment ard documentation, and ansivers questions or finds someone who can give the answer.

Broad Base of Community Support: New Mexico Technel crealed a partnership of universities, national laboratories, and businesses together with public and private high schouls throughout the state to sponsor the Challenge.

\subsection{Implementation}

The Challenge proceeds through six phases during the academic ycar, wi'h continuous eval ation and fecdback throughoul.

Phase 1. Call for Partlcipation: The Challenge begins at the start of the academic year with a call for participation for teanis to do computational science projects using high-performance computers. Teachers and students form teams and enter the Challenge by describing, in general terms, the scientific area and project they plan to work on.

Phase 2. Introductory Workshop: A two-day workshop is held in the fall for all students and teachers, where they are introduced to computational science and leam basic computing on supercompuicrs.

Phase 3. Inltial Work: After the initial workshop, students retum to their schools to begin tackling Uleir problein. Many students must ulso Ieam a scientific programming langunge such as Fortray or $C$. With guidance from their Ieclinical coach bid their Ieacher, the team members set up the problein and leam abou' what w'l! be necded to solve it. At the end of this phase. students write a report of $2(x)$ words or less describing the team's project and their 
progress.

Phase 4. Computing: The computing phase of the project is the most exciting and frustrating to the students. The Consulting Office at Los Alamos is in great demand at this time answering programming questions and examining problems.

Students, with the help of their lechnical coach, define an algorithm to solve their problem. Then, they write a computer program to run on the supercomputer, or they may obtain an existing scientific application code and focus on simulation or data analysis.

Phase 5. Final Report: Students complete their project by late April, write a final repor, and creace a poster display. Because of the diverse computing background of students entering the competition, projects may be submitted in either of two categories.

Cate ory 1 projects are for teans who have made progress in lcaming to work on a computer but were not able to make significant progress on their problent. Their report includes what they $r$ ve leamed about their project and what they have learned about supercompurers, programming, and communications on the super-computers. During next year's cempetition, these teams maly continue working on their problem to carry it dirough wo coinpletion.

Category 2 projects are for teams who have more computing background and made significall progress with their computing projects. Their report includes a statement of the problem being investigated, description of the method of solution, results of the investigation, conclusions drawn from the analysis, and supponing evidence. In the next year, these tcams may further define their proicets and submit them to the natinnal comnctitions. In addition, individual students submit reports describing their leadership, involvement, and accomplishments.

Phose 6. Judging and Awards: Leading scientific and computing experts drawn from research laboratorics and universities in the region are asked to participate as judges. They are selected before the beginning of the Challenge and are kept informed of the directions and support given to the teams. The judges visit the teams at the schools to Lalk with Lie students about the projects.

The projects are judged axcording to the following critcria. 


\begin{tabular}{lr} 
Scientific content & 30 points \\
Effectiveness of approach & 30 points \\
Creativity & 30 J jints \\
Clarity & 10 points \\
\cline { 2 - 2 } Total & 100 points
\end{tabular}

At the culmination of the competition, all teams autend a one-day awords ceremony and science tour in early May at Los Alamos where they get to sce the computers they have been using. Each member of a team that completes the Challenge by submitung a report in Category 1 or 2 receives a scientific calculator for project completion.

Awards for Category 2 teams for the 1990-1991 competition included: first-place awards of a \$1,000 savings bond for each stucient on the team and computer equipment for the school; second-place awards of a $\$ 500$ savings bond for each student on the team and computer equipment for the school.

In addition, to team excellence, individual excellence is also judged. This is based on a scparate repon writlen by a student and substantiated by letters of recommendation from the teacher and technical coarh. The reporn and letters describe the individual's involvement and leadership in the project. Three scholarships are awarded, one to each of University of New Mexico, New Mexico State University, and New Mexico Insuitule of Mining and Technology.

Phase 7. Evaluation and Feedback: In c,der to meet the needs of teachers, students, and coaches, feedback from all participants is continuelly monitored. We evaluate the quality of the projects relative to the computing background of the teams and observe computer usage ume and number of participants, noting the involvement of groups that are historically under-represented in science.

\section{Other High School Supercomputing Programs}

There are several otier well-known programs at the statc and naticnal levels that usc supercomputers to enhance scicnce education for high schools. Like the New Mexico program, the Alabama program [8] is nonselective and serves both average and exceptional high school students, but its community of involved schools and sludents is somewhat smaller and only the Cray supercomputer architecture is available. The Alabania program has a strong teacher education component.

Other competitions, such as the SuperQuest national competition $[9]$ from Concll Nattional Supercomputing 
Facility, et al; the National High School Supercomputing Honors Program [10] from Lawrence Livermore National Laboratory; and the North Carolina compecition [11], are sclective and serve the exceptional high school students.

\section{Resuits}

This project was underta'sen with virually no preplanning. From the beginning, the idea intrigued everyone, and we decided to try it. We had the scientific and computational resources, and the organizers had assembled people with administrative, iducational, marketing, and technical experise. We were aware of some of the other programs around the country and could draw on their experiences.

We were surprised and pleased by the level of interest among teachers and students from throughout the state, and we were delighted that $80 \%$ of the original paricipants completed the Challer. ge.

The students and teachers prolited from the program in many ways.

- They leamed aboul compuling and science.

- Students' horizons were expanded, and science and technology have a greater place in their lives.

- Teachers' view of the role of computing in the classroom and science was 'widencd.

- Students came away with a new interest in science and computing as a carecr.

Many people consider the Clibllenge a success. The broad base of community suppon-including New Níexico Technet, national laboratorics, universities, computer vendors, businesses, and schools-were pleased with the program and its resilts. The judges were impressed with the quality of the projects and the creativity and resourcefulness shown by the paricipants. The participants gave the Challenge a vole of approval when all nongraduating studenti said they planned to lake part again

Additional oi servations include the following:

- The goals of promoting intcrest in science and computing and increasing students' knowledge in uhese arcas can be achieved U:rough this type of program. 
- Ongoing support is critical to identifying hurdles and addressing them rapidly. Teachers have litue time to spend on troubleshooting and seeking solutions to problems.

- Technical coaches are necessary to give direction to the projects and individualized support in science and computing.

- A non clive program is key to achieving broad participation leading to broad benefíts.

\subsection{Unanticipated Results}

The high level of interest in the Challenge was totlly uncxpected-20\% of New Mexico high schools participated in this first Challenge. Students and teachers have . cen very enthusiastic.

It is possible to put together a program such as this in a very short ume. Solicitation and commitment of sponso.s and resources was oblained in only a few wacks. The program was defined and structured in that same shon time period.

\section{Future Plans}

We plan to offer the New Mexico High School Supercomputing Challenge as a yearly competition, and as students' and leachers' knowledge and experience grow. their projects will leed into the national competitions. B:"' conlinuing to obtain feedback and evaluate results, we will adapt and improve the program to meet the needs. of the participants and encourage a high level of academic excellence.

While we were plensed with the level of participation of the historically underrepresented groups (25\% women, $30 \%$ minotities), we intend to take specific artion to inform representative organizations of the Challenge and to idenify ways to encourage greatcr paricipation.

Additional training and understanding of scientific computing and the use of supercomputers in science nust he proviciet for teachers. Possible professiundal development programs include a six-week summer institute in compulational science and severil tegional on:-day in-scrvice workshups. 


\section{Summary}

The New Mexicu Supercomputing Challenge is presented as a link between the education communities and the science communities, both locally a.J national': I! enhances the knowledge of high school teachers and sudents in science and computing; it increases the understanding of education realities and opportunities by scientists; and it ups ine potential for community benefits offered by scientists and the energy and desire to learn of leachers and students.

The Challenge is an effective wiy of encouraging students wi discover the excitement of science and computing. The enchusiasm generaled by aademic success can provide the impetus to pursue a career in science and computing.

The Challenge nay serve as a model that can the entanced and adapted by other localities. A nationwide scheme of local programs leading to the nacuonal I:vel will increare the level of interest and the number of students participating in scientific and computing endeavcrs and foster higher levels of academic achievenent

Without the .nflux of significart science and computing expertise ind resourees into ...gh school educational comm ies, high school teachers cannot by themselves enhance science education. The Chaininge uses scisntific and cor utational expertise existing in research laboratories and universities, in collaboration with education communities, to make a difference in high school science an 1 mulhematics educaticin.

By combining sciense and computing with a high school activity of high visibility and excicment, students, parer.ts, and teachers are auracted and will leam more shisut sicntific computation and the multidisciplinary approach to scienufic problcms.

\section{Acknowledgm:2nts}

This program was the result of stat -hide suppon bv busines... national bboratorics, and universities. It was made possible through the gener us suppert and contubutions nf many people and organizations.

Terry Boulanger and New Mexico Technet have been unstrumental in creating and coordinating the Challenge and in arserib!ıng a parenership of Susinesses. universiues. national laboratorics. and public and private sihools throughout the state New Mexicn Technet ato provided funds advertising. fond and lodging, workshop materials. training, computer equipment, awarts, and sansporation. 
University of New Mexico, New Mexico State University, and New Mexir o Institute of Mining and Technology donated scholarships for outstanding individuals in the competition, and they were involved in tcacher supporn, coaching, judging, and administration. Ar SL George and John Jenkins of UNM deserve special thanks.

Sandia National Laboratories and Phillips Laboratory (Air Force Weapons Laboratory) were involved as coaches and judges and provided additional funding.

With the suppon of Sig Hecker, Norm Morse, and Hassan Dayem, Los Alamos National Laboratory contributed cosches and judges, speakers, computer consulants. teacher and student suppon, teaching assistants, and administrative suppor; network connections and high-performance computing resources; eomputer ciocumentation, videolapes, and ocher instructional matcrials; computung equipment for schools; and facilities and food for workshops. We especially thank the support suff tho handled the logistics necessary for inceings of 300 people.

We appreciate ule alvice and materials given by John Ziebarth of the Alabama Supercomputing Center and Helen Doerr of the Comell Theory Center. They were very helpful.

Most of all, we thank the 40 coaches, 55 teachers, and 235 students, who devoted their time and energy to this effor, and the school adminisurabrs who had the foresight to support it. Without these penpie, there would have been no Challenge.

\section{References}

[1] Lax, P. Report of the Panel on Large Scale Computing in Science and Engineering. Sponsored by the U.S. Department of Defense ariJ the National Science Foundation, in conperation with the Depar'nent of Energy and the National Aeronautics and Space Administrauon, Washıngınn, D.C., 1982.

12] Natonal Commission on Excellence in FJucition. A Nution at Risk. A Repon to the Natuon and the Secrelirs of Education. 1983.

[3] American Association for the Advancement of Sulence. Sitence for All Americans. A Summary of Prolkel 2061. 1989 
[4] Bardon, M. and K. Curis. A Narional Compuing Environmens for Acadenuc Research. NSF Working Group on Computers for Research, National Science Foundation. 1983.

[5] Sman, L. and N. Sabelli. Compuational Science and Engineering Education: Workshop on the Role of Supercompuring Cenlers in Science Education. NSF Grant No. ASC-90180!1, 1991.

[6] Sabelli, N. Compurational Science and Enginesring in Education: Role of High-Perfurmance Computing in Science Education. Submitted to the Intemational Journal of Supercomputing Applications.

17) Malone, P. and H. Dayem. "The New Mrzico Supercompuler Challeage," Compuring and Communication, News. Los Alamos repon LALP-90-2(9-90), Novembur 1990, pp. 5.6.

[8] Camuth, S. "Position Paper for Compulational Science and Education," NSF Wicrkshop on the Role of Iligh Performanze Compi:ing in Education, 1990.

[9] Comell Supercomputing Center, et al. SuperQuere, 1900

[10] Shuler, J. "Position Puper for Computational Science and Education," NSF Workrhop on the Rnle of Mligh Performonce Compuling in Eciucation, 19(x).

(11) North Carolina Supercomputing Cenicr. SuperQue,st: The North Carolina Connectinn, 1991. 